\title{
Biopshychosocial and Economic Determinants of Personal Hygiene in the Prevention of Diarrheal Diseases in Sragen District, Central Java
}

\author{
Hervindita Dinda Siswandwika1), Bhisma Murti²), Ruben Dharmawan2) \\ ${ }^{1)}$ Masters Program in Public Health, Sebelas Maret University \\ 2)Faculty of Medicine, Sebelas Maret University
}

\begin{abstract}
Background: Poor environmental sanitation and personal hygiene have been shown to be associated with increased risk of diarrheal disease. Poor personal hygiene that is associated with an increased risk of diarrheal disease may be explained by the constructs of Health Belief Model, such as perceived susceptibility and perceived seriousness. This study aimed to examine biopshychosocial and economic determinants of personal hygiene in the prevention of diarrheal diseases.

Subjects and Method: This was an analytic observational study with case control design. This study was conducted at Mondokan, Gesi, and Sambungmacan Health Centers, Sragen District, Central java, from January to March, 2017. A sample of 150 subjects, consisting of 50 cases of diarrheal disease during the past month and 100 subjects without diarrheal disease, was selected in this study by purposive sampling. The dependent variable was prevention behavior of diarrheal disease. The independent variable included perceived susceptibility, seriousness, threat, benefit, barrier, cues to action, and self-efficacy. The data was collected using a pre-tested questionnaire, and analyzed by path analysis model.

Results: There were positive, and statistically significant effects of perceived seriousness $(b=0.26$; $\mathrm{SE}=0.06 ; \mathrm{p}=<0.001)$, threat $(\mathrm{b}=0.29 ; \mathrm{SE}=0.06 ; \mathrm{p}=<0.001)$, benefit $(\mathrm{b}=0.21 ; \mathrm{SE}=0.06 ; \mathrm{p}=$ $<0.001)$, barrier $(b=-0.12 ; \mathrm{SE}=0.08 ; \mathrm{p}=0.032)$, cues to action $(\mathrm{b}=0.17 ; \mathrm{SE}=0.07 ; \mathrm{p}=0.003)$, and self-efficacy $(b=0.28 ; \mathrm{SE}=0.14 ; \mathrm{p}=<0.001)$ on prevention behavior of diarrheal disease. There were positive, indirect, and statistically significant effect of perceived susceptibility $(b=0.55 ; \mathrm{SE}=$ 0.06; $\mathrm{p}=<0.001)$, seriousness $(\mathrm{b}=0.34 ; \mathrm{SE}=0.06 ; \mathrm{p}=<0.001)$, and benefit $(\mathrm{b}=0.12 ; \mathrm{SE}=0.07 ; \mathrm{p}=$ o.025) on prevention behavior of diarrheal disease, via perceived threat.

Conclusion: Perceived seriousness, threat, benefit, barrier, cues to action, and self-efficacy, are direct determinants of prevention behavior of diarrheal disease. Perceived susceptibility, seriousness, and benefit, are indirect determinants of prevention behavior of diarrheal disease.
\end{abstract}

Keywords: biopshychosocial, economy, personal hygiene, health belief model

\section{Correspondence:}

Hervindita Dinda Siswandwika. Masters Program in Public Health, Sebelas Maret University.

Email: vindy_7@yahoo.com. Mobile: +6282136242777.

\section{BACKGROUND}

The degree of community health is influenced by the factors of environment, health service facilities and behaviors. The factors of environment and behaviors heavily influence the success of health development that emphasizes the aspects of prevention rather than medication (Kemenkes RI, 2015). The condition of environmental health in Indo- nesian has been concerning. The poor environmental sanitation and individual hygiene has been marked by the high figures of infectious and contagious disease outbreak in community (Taozu and Azizah, 2013; Sukut, 2015).

According to the Ministry of Health Republic of Indonesia (Kemenkes RI, 2013), Indonesian citizens who have been living 
Journal of Health Promotion and Behavior (2017), 2(1): 1-14

https://doi.org/10.26911/thejhpb.2017.02.01.01

under poor condition achieve 72.5 million in cities (18.20\%) and villages (40.00\%). Among the members of ASEAN and SEAR, Indonesia has occupied the bottom four in terms of sufficient sanitation facilities. Even in the provinces with good performance (Central Java and Yogyakarta Special Region), one of three households does not have access to clean water (UNICEF Indonesia, 2012). A crucial problem in the domain of sanitation and hygiene has been the behavior of defecating inappropriately (BABS, buang air besar sembarang). Households that do not have defecation facilities have been $17.78 \%$ (Kemenkes RI, 2013).

Death due to waterborne disease achieves 3.4 million people/ year. From all deaths due to the poor quality of water and sanitation, diarrhea has been the biggest cause with 1.4 million people/year as its mortality figure. Diarrhea has also been the first cause of death among babies (31.40\%) and toddlers (25.20\%) and has been the fourth cause of death in all age group (13.20\%) (WSP, 2008; WHO and UNICEF, 2014; Anup, 2012).

The figures of diarrhea outbreak in households that use open-air well are $34.00 \%$ higher than those of households that use water-pipe. Then, the figures of diarrhea outbreak are 66.00\% higher among the families that defecate in openair area thanthose that defecate in the family closet and septic tank (UNICEF Indonesia, 2012). In 2015, there were 18 times of diarrhea extraordinary case in 18 provinces and 18 regencies/cities and the number of diarrhea patients in these cases was 1,213 people with mortality rate 30 people. The Diarrhea CFR during this extraordinary case drastically improved approximately 2.47\% (Kemenkes RI, 2016). The cause of high figure on the environmental-based contagious disease has been the poor hygienic behavior and quality of communal life (Dreielbis et al., 2003). According to ISSDP (2015), 47.50\% of water that has been consumed contains $E$-coli and $47.00 \%$ of community members still defecate in open-air area.

Indonesia is the second country in which the practice of inappropriate defecation has occurred (12.90\%) after India (58.00\%) (WHO, 2014). In villages on the Province of Central Java, households that have sufficient sanitation (healthy closet) have been decreasing from $77.00 \%$ in 2014 into 67.20\% in 2015 (Dinkes Jateng, 2016). In 2015, there has been 7,596 cases of diarrhea on the Regency of Sragen. The use of closet as defecation facility is still low. The highest practice of inappropriate defecation has been found in Mondokan (done by 5,164 people, 42.00\%), Sambungmacan (done by 2,070 people, 15.00\%) and Gesi (978 people, 15.00\%) (Dinkes Sragen, 2016).

The theory of Health Belief Model (BFM) that was developed by Rosenstock (1966) explains and predicts the possibility of associating behavioral changes to the pattern of certain belief or feelings (Hayden, 2010; Nelas et al., 2015). A previous study by Dahal et al. (2014) and Schmidlin $\mathrm{T}$ et al., (2014) stated that knowledge, practice, economy, social-culture and belief of an individual have been related to hygienic behaviors. Therefore, this study then aimed at explained the influence of bio-psycho-social and economic determinants regarding individual hygiene toward the behaviors of Diarrhea prevention by implementing the theory of Health Belief Model (BFM).

\footnotetext{
SUBJECTS AND METHOD

This quantitative study made use of observational analytical design with case-
} 
control framework. The study was conducted in the Regency of Srafgen, the Province of Central Java, from January until March 2017. The population in this study was the people in the Regency of Sragen. The sample was gathered through purposive sampling technique and fixed disease sampling. The total sample was 150 subjects who were divided into the case group, namely 50 Diarrhea patients within the last one month, and the control group, namely 100 Diarrhea patients that had been gathered from the working region of Mondokan Community Health Center, Sambungmacan Community Health Center and Gesi Community Health Center in the Regency of Sragen. The instrument that the researchers applied in measuring the variables on perceived vulnerability, perceived severity/ seriousness, perceived threats, perceived benefits, perceived barriers, cues action and selfefficacy was Health Belief Model (HBM) questionnaire. The measurement scale was continuous; for the sake of analysis and description importance, the continuous data would be changed into the categorical data if the score were low $(<$ mean) or were high ( $\geq$ mean).

Perceived vulnerability was the subjective perception regarding the risk of being affected to a disease, which referred to the risk of an individual suffering from certain disease. The greater the risk an individual perceived, the greater the possibility to be involved in risk-decreasing actions. Then, perception of seriousness was the belief regarding the level of disease seriousness or severity level (including evaluation of medical, clinical and social consequence that might appear) that an individual might have difficulties due to the disease that he or she had and the fact that this disease might bring about negative impact to his or her life in general.
Perceived threats were the encouragement to perform prevention and medication toward a disease due to the perceived vulnerability and severity/ seriousness. Too enormous threat would cause fear that inhibited healthy behaviors display because an individual had been helpless in combating his or her disease. Furthermore, perceived benefits were the perception regarding the value of new behavior usefulness in decreasing the risk of being affected by disease both the physical and the mental usefulness. An individual would be inclined to adopt healthy behaviors due to his or her belied that these behaviors had healthy usefulness. Next, perceived barriers were the negative consequence that occurred when an individual took a new action physically, psychologically or financially. In relation to the behaviors that had been adopted, an individual should believe that the benefits that he or she retrieved would be greater than the consequence of continuing his or her old behaviors.

Cues to action was the factors that encouraged an individual to adopt diseasepreventing behaviors and it might be external and internal factors such as: mass media, suggestions, personal or familial experiences and more regarding healthy behaviors. Self-efficacy referred to the belief/the self-efficacy in performing healthy behaviors. If an individual believed the usefulness of new behaviors, but he or she thought that he or she were inhibited to do these new behaviors, then these new behaviors would not be performed. Next, Diarrheapreventing behaviors referred to the healthy behaviors that individual performed in order to prevent him or her from getting affected by Diarrhea regarding healthy closet use, clean water facilities availability and use and hand-washing habit.

Previously the researchers had conducted a face validity test and a content 
Journal of Health Promotion and Behavior (2017), 2(1): 1-14

https://doi.org/10.26911/thejhpb.2017.02.01.01

validity test by Pearson product moment correlation technique. Then, the researchers performed a reliability test by Alpha Cronbach technique. The validity and reliability was conducted by involving 20 community members who shared similar characteristics from different locations.

The secondary data were taken from medical records and patient visit books in the community health centers. The primary data were attained from the results of direct observation toward the subjects' settlement and questionnaire. The researchers then performed a multivariate analysis by Path analysis with IBM SPSS AMOS 22 software in order to test the relationship between the exogenous variables (perceived vulnerability, perceived severity/ seriousness, perceived benefits, perceived barriers, cues to action and self-efficacy) and the endogenous variables (perceived threats and individual hygiene on Diarrhea preventing behaviors).

\section{RESULTS}

In this section, the researchers discuss the characteristics of the subjects and the results of path analysis.

\section{Table 1. Subjects characteristics}

\begin{tabular}{|c|c|c|c|}
\hline \multirow{2}{*}{ Characteristics } & \multirow{2}{*}{ Criteria } & \multirow{2}{*}{$\begin{array}{c}\text { Case }(n=50) \\
n(\%)\end{array}$} & \multirow{2}{*}{$\begin{array}{c}\text { Control }(\mathbf{n}=100) \\
\mathbf{n}(\%)\end{array}$} \\
\hline & & & \\
\hline \multirow[t]{2}{*}{ Sex } & Female & $28(56.0)$ & $68(68.0)$ \\
\hline & Male & $22(44.0)$ & $32(32.0)$ \\
\hline \multirow[t]{3}{*}{ Age } & 18-40 years old & $28(56.0)$ & $56(56.0)$ \\
\hline & 41-6o years old & $20(40.0)$ & $37(37.0)$ \\
\hline & $\geq 61$ years old & $2(4.0)$ & $7(7.0)$ \\
\hline \multirow[t]{2}{*}{ Status } & Single & $\mathrm{o}(0.0)$ & $9(9.0)$ \\
\hline & Married & $50(100.0)$ & $91(91.0)$ \\
\hline \multirow[t]{2}{*}{ Education } & $<$ Senior High School & $31(62.0)$ & $29(29.0)$ \\
\hline & $\geq$ Senior High School & $19(38.0)$ & $71(71.0)$ \\
\hline \multirow[t]{8}{*}{ Occupation } & Housewife & $7(14.0)$ & $21(21.0)$ \\
\hline & Farmer & $10(20.0)$ & $8(8.0)$ \\
\hline & Farming Labor & $12(24.0)$ & $3(3.0)$ \\
\hline & Entrepreneur & $9(18.0)$ & $21(21.0)$ \\
\hline & Trader & $8(16.0)$ & $8(8.0)$ \\
\hline & Private company employer & $1(2.0)$ & $16(16.0)$ \\
\hline & Factory labor & $2(4.0)$ & $5(5.0)$ \\
\hline & Civil servant & $1(2.0)$ & $18(18.0)$ \\
\hline \multirow[t]{2}{*}{ Family income } & $<$ Regional Minimum Wage & $46(92.0)$ & $48(48.0)$ \\
\hline & $\geq$ Regional Minimum Wage & $4(8.0)$ & $52(52.0)$ \\
\hline \multirow{8}{*}{$\begin{array}{l}\text { Number of fami- } \\
\text { ly head }\end{array}$} & 2 people & $\mathrm{o}(0.0)$ & $6(6.0)$ \\
\hline & 3 people & $1(2.0)$ & $11(11.0)$ \\
\hline & 4 people & $14(28.0)$ & 19 (19.0) \\
\hline & 5 people & 14 (28.0) & 36 (36.0) \\
\hline & 6 people & $13(26.0)$ & $16(16.0)$ \\
\hline & 7 people & $7(14.0)$ & $9(9.0)$ \\
\hline & 8 people & $1(2.0)$ & $2(2.0)$ \\
\hline & 9 people & $\mathrm{o}(0.0)$ & $1(1.0)$ \\
\hline \multirow{2}{*}{$\begin{array}{l}\text { Sanitation facili- } \\
\text { ties availability }\end{array}$} & Unavailable & $27(54.0)$ & $13(13.0)$ \\
\hline & Available & 23 (46.0) & $87(87.0)$ \\
\hline
\end{tabular}

Table 1 explains that from 150 subjects there are 96 female respondents. The average age of the subjects, both for the case group and the control group, is 18-40 years old. Most of the subjects have been married. In terms of educational characteristics, the educational background for most of the subjects in the case group is under senior high school (62.00\%) while the educational background for most of the 
subjects in the control group is senior high school and above (71.00\%).

According to the results of the study, $\mathbf{2 4 . 0 0 \%}$ of the subjects in the case group are working as farming labors and $21.00 \%$ of the subjects in the control group are working as housewives and entrepreneurs. 92.00\% of the subjects in the case group earn under-regional minimum wage income namely IDR $1,422,585$. The distribution of subject characteristics based on the number of family head shows that most of the family members who live in the same house for the case group have been 4 to 5 people (28.00\%, while most of the family members who live in the same house for the control group have been 5 people (36.00\%).

The description on the availability of sufficient sanitation is as follows: $54.00 \%$ sufficient sanitation has not been available in the case group, while $87.00 \%$ sufficient sanitation has been available in the control group. Path analysis is conducted in order to identify the size on the influence of a variable, both the direct and the indirect influence. The size of the independent variable influence toward the dependent variable is referred to path coefficient. On the contrary, path coefficient itself does not have any unit; therefore, the researchers might conclude that the greater the path coefficient the greater the influence that the variable results. The inter-dependent and independent variable relationship will be established through the mediator variable and then will be analyzed by means of path analysis model.

This study consists of six exogenous variables namely perceived vulnerability, disease severity, benefit, barriers, cues for taking action, and self-efficacy. Then, the intervening variable will be the variable that has been influenced or that had influenced other variables, in this case the perceived threats. On the other hand, the endogenous variable in this study will be individual hygiene regarding Diarrhea preventing-behaviors. There are also several observed variables namely perceived vulnerability, severity, threat, barriers, cues to action, self-efficacy and individual hygiene regarding Diarrhea prevention. The data are processed by IBM SPSS AMOS 22 and the results are displayed in Picture 1 . The results on the degree of freedom (df) have been 4 which implies that the data had been over identified or the path analysis might be conducted. Picture 1 shows the structural model after estimation has been conducted.

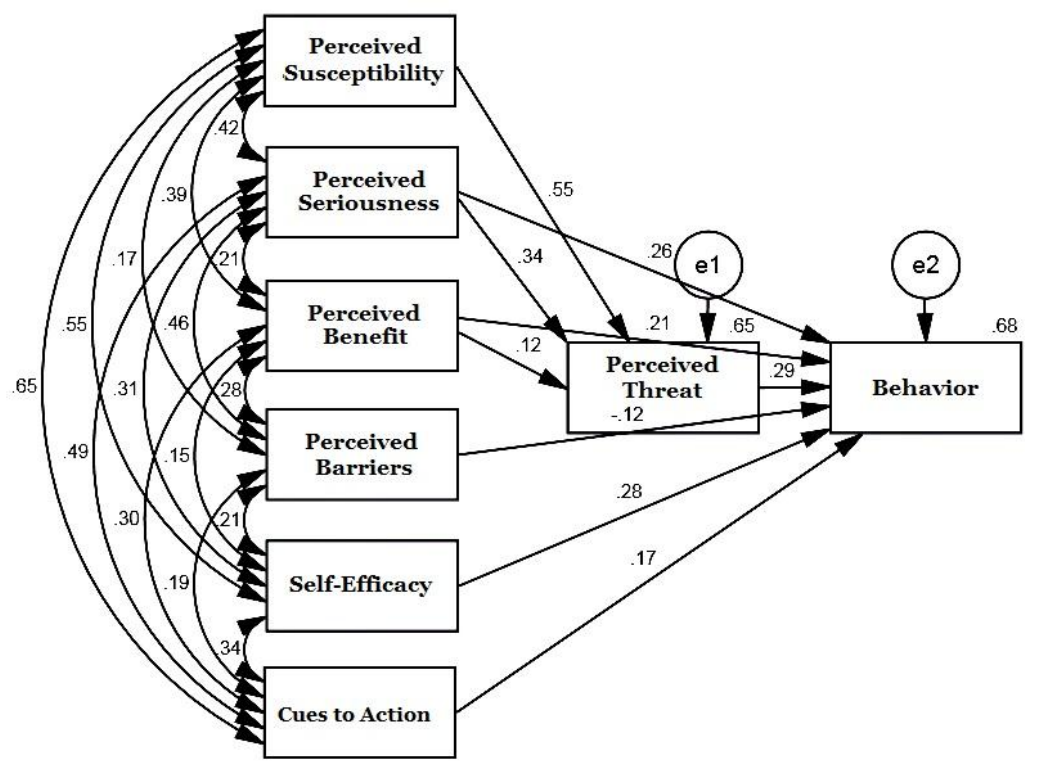


Journal of Health Promotion and Behavior (2017), 2(1): 1-14

https://doi.org/10.26911/thejhpb.2017.02.01.01

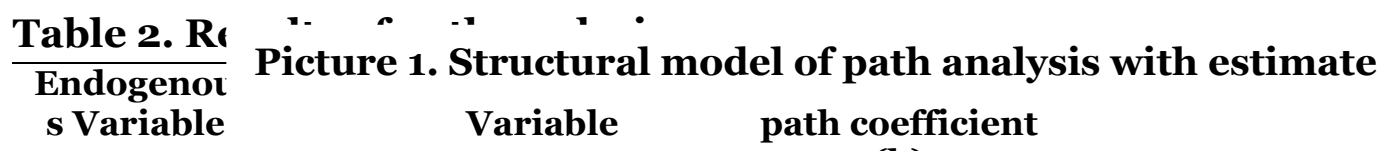

\begin{tabular}{|c|c|c|c|c|c|c|}
\hline & & & (b) & & & (ß) \\
\hline & rect re & lationship & & & & \\
\hline $\begin{array}{l}\text { Diarrhea- } \\
\text { preventing } \\
\text { behaviors }\end{array}$ & $\longleftarrow$ & $\begin{array}{l}\text { Perceived } \\
\text { severity/seriousness }\end{array}$ & 0.24 & 0.06 & $<0.001$ & 0.26 \\
\hline $\begin{array}{l}\text { Diarrhea- } \\
\text { preventing } \\
\text { behaviors }\end{array}$ & $\leftarrow$ & Perceived threats & 0.25 & 0.06 & $<0.001$ & 0.29 \\
\hline $\begin{array}{l}\text { Diarrhea- } \\
\text { preventing } \\
\text { behaviors }\end{array}$ & $\leftarrow$ & Perceived benefits & 0.23 & 0.06 & $<0.001$ & 0.21 \\
\hline $\begin{array}{l}\text { Diarrhea- } \\
\text { preventing } \\
\text { behaviors }\end{array}$ & 4 & Perceived barriers & -0.17 & 0.08 & 0.032 & -0.12 \\
\hline $\begin{array}{l}\text { Diarrhea- } \\
\text { preventing } \\
\text { behaviors }\end{array}$ & $\leftarrow$ & Cues to action & 0.19 & 0.07 & 0.003 & 0.17 \\
\hline $\begin{array}{l}\text { Diarrhea- } \\
\text { preventing } \\
\text { behaviors }\end{array}$ & $\leftarrow$ & Self-efficacy & 0.76 & 0.14 & $<0.001$ & 0.28 \\
\hline & direct 1 & relationship & & & & \\
\hline $\begin{array}{l}\text { Perceived } \\
\text { threats }\end{array}$ & $\longleftarrow$ & $\begin{array}{l}\text { Perceived } \\
\text { vulnerability }\end{array}$ & 0.60 & 0.06 & $<0.001$ & 0.55 \\
\hline $\begin{array}{l}\text { Perceived } \\
\text { threats }\end{array}$ & $\longleftarrow$ & $\begin{array}{l}\text { Perceived } \\
\text { severity/seriousness }\end{array}$ & 0.37 & 0.06 & $<0.001$ & 0.34 \\
\hline $\begin{array}{l}\text { Perceived } \\
\text { threats }\end{array}$ & $\longleftarrow$ & Perceived benefits & 0.15 & 0.07 & 0.025 & 0.12 \\
\hline Model Fit & & & & & & \\
\hline $\begin{array}{l}\mathrm{CMIN}= \\
4.604\end{array}$ & $\mathrm{p}=\mathrm{o}$. & $330(\geq 0.05)$ & & & & \\
\hline GFI = 0.99 & $(\geq 0.9$ & & & & & \\
\hline $\mathrm{NFI}=0.99$ & $(\geq .90$ & & & & & \\
\hline $\mathrm{CFI}=0.99$ & $(\geq 0.9$ & & & & & \\
\hline $\begin{array}{l}\text { RMSEA = } \\
0.032\end{array}$ & $(\leq 0.0$ & & & & & \\
\hline
\end{tabular}

andardized oefficient $-$

.

ed threats, perceived benefits, perceived barriers, cues to action, and self-efficacy.

1. There has been indirectly positive influence between perceived vulnerability and Diarrhea-preventing behaviors through perceived threats $(b=0.55 ; p<0.001)$; this relationship is significant.

2. There has been directly positive influence $(b=0.26 ; p<0.001)$ and indirect $(b=0.34 ; p<0.001)$ between perceived severity/ seriousness and Diarrhea-preventing behaviors through perceived threats; this relationship is significant.

3. There has been indirectly positive influencebetween perceived threats and Diar- 
rhea-preventing behaviors $(\mathrm{b}=0.29$; $\mathrm{p}<$ o.001); this relationship is significant.

4. There has been directly positive influence $(b=0.21 ; p<0.001)$ and indirect $(b=0.12 ; p<0.025)$ between perceived benefits and Diarrhea-preventing behaviors through perceived threats; this relationship is significant.

5. There has been directly negative influence between perceived barriers and Diarrhea-preventing behaviors $(b=0.12 ; \mathrm{p}=$ o.032); this relationship is significant.

6. There has been indirectly positive influence between cues to action and Diarrhea-preventing behaviors $(b=0.17 ; p=$ o.003); this relationship is significant.

7. There has been directly positive influence between self-efficacy and Diarrheapreventing behaviors $(b=0.28 ; \mathrm{p}<$ o.001); this relationship is significant.

\section{DISCUSSION}

1. The influence of perceived vulnerability toward Diarrhea-preventing behaviors

The results of the study show that there has been indirect influence from perceived vulnerability toward Diarrhea-preventing behaviors through perceived threats $(b=0.55$; $\mathrm{p}<0.001)$. This implies that an individual who perceives that his or her body is vulnerable to Diarrhea will have greater possibility to adopt Diarrhea-preventing behaviors thanan individual whose perception is that his or her body is not vulnerable to Diarrhea.

An individual who refuses to adopt healthy behaviors have smaller possibility to belief that the behaviors of individual hygiene are very necessary to protect the family health thanan individual who adopts Diarrhea-preventing behaviors. If an individual perceives that he or she has a risk of getting infected by a disease, then this in- dividual will perform safe behaviors and disease-preventing efforts.

According to Rosenstock (1982) in Orji et al. (2012), people who perceive that they easily get affected by a disease will be easier to feel threatened. This threat will encourage an individual to perform diseasepreventing or disease-medicating behaviors. In this study, the researchers still find the respondents who feel that they are vulnerable to Diarrhea (34.70\%). If an individual perceives that he or she is not vulnerable to a disease, then he or she should be provided with more intensive stimuli so that this individual will display necessary responses for his or her health. This sense of being invulnerable might be caused by the minimum knowledge regarding the danger of the disease itself (Vega, 2013). There should be efforts toward improving the knowledge through both individual and communal health education.

\section{The influence of perceived disease severity toward Diarrhea-prevent- ing behaviors}

The results of the study show that there has been direct $(b=0.26 ; p<0.001)$ and indirect $(b=0.34 ; p<0.001)$ influence from perceived disease severity toward Diarrheapreventing behaviors through perceived threats $(b=0.34 ; p<0.001)$. This relationship implies that an individual who strongly perceives that Diarrhea is a serious disease will have greater possibility to adopt Diarrhea-preventing behaviors than an individual who perceives that Diarrhea is not a serious disease and does not threat his or her health.

The perceived severity/ seriousness/ seriousness refers to an individual's feelings regarding the severity of a disease and includes evaluation toward clinical and medical consequence (death, disability and pain) with social consequence that might appear (impact toward occupation, family 
Journal of Health Promotion and Behavior (2017), 2(1): 1-14

https://doi.org/10.26911/thejhpb.2017.02.01.01

life and social relationship). Individual absorbs new behaviors; at the begining he or she should understand first the meaning or the benefit of these new behaviors for himself or herself and for his or her family (Hayden, 2010; Sigler, 2015). The behaviors that have been based on knowledge will last longer than the ones that have not been based on knowledge. Furthermore, the knowledge itself will create a mental response in the form of an attitude toward the object that has been known. The attitude that has been attained through experience creates direct influence toward the following healthy behaviors (Vega, 2013; Sigler, 2015).

The data in this study show that there have been some community members who perceive that Diarrhea is not a serious disease and does not threaten their health (42.70\%). The reason is that individual hygiene has not been their main option in the Diarrhea-preventing behaviors due to the minimum knowledge that these members have. As an effort to improve the perceived severity/ seriousness, there should befurther information regarding the danger of Diarrhea. If the perceived severity/ seriousness has improved, then the preventing behaviors will have been better as well (Jasper \& Bartram, 2012).

\section{The influence of perceived threats toward Diarrhea-preventing beha- viors}

The results of this study show that there has been direct influence from perceived threats toward Diarrhea-preventing behaviors $(b=0.29 ; p<0.001)$. This implies that an individual who perceives that Diarrhea is a disease that threatens his or her health will have greater possibility to adopt the preventing behaviors than the one who perceives that Diarrhea is not a threatening disease.
According to Rosenstock (1982) in Burke (2013), individual view regarding the severity of a disease (perceived seriousness), namely the risk and the difficulty that might be experienced due to suffering from the disease, will encourage the individual to feel easily affected or to be vulnerably affected by the disease. On the other hand, individual perception regarding the possibility of getting affected by Diarrhea (perceived susceptibility) encourages them to feel easily threatened (perceived threats). The results of this study are in accordance to a study by Schmidlin et al. (2013) that perceived vulnerability and perceived severity/ seriousness causes higher perceived threat. This threat encourages individual to adopt disease-preventing or medicating action.

According to the theory of HBM, healthy behaviors might appear and be maintained due to the commitment to perform healthy behaviors and the presence of fear toward the threats of a disease. Individual commitment is influenced by behavioral specific cognitions and affect that include namely: perceived benefits, perceived barriers, self-efficacy, interpersonal influence and perceived threat of disease (Fauziah et al., 2015).

In this study, the researchers still find that there are individuals who consider diarrhea as non-health threatening disease $(34.70 \%)$. The reason is that the understanding with regards to the threats that a disease might have will be different in each individual, depending on his or her medical knowledge regarding the disease. It will be better if the individual is provided with health education in order to improve the community members' knowledge regarding individual hygiene so that perceived threats might be improved and might motivate the community members to pursue healthy behaviors. 


\section{The influence of perceived benefits toward Diarrhea-preventing beha- viors}

The results of this study show that there has been direct $(b=0.21 ; p<0.001)$ and indirect $(b=0.12 ; p=0.025)$. This implies that an individual who have perceives that individual hygiene is useful will have greater opportunity to adopt Diarrhea-preventing behaviors than the one who does not have perception that individual hygiene is not useful.

Perceived benefits are an individual's belief in taking disease-preventing actions, disease-protecting actions and diseasesmedicating actions in order to decrease his or her vulnerability toward the disease or the disease severity as well as an individual's confidence on the effexctivenss of their actions in decreasing the risks caused by the disease (Smith et al., 2011; William et al., 2015).

The results of this study show that an individual will perform Diarrhea-preventing actions if here or she feels that the actions are useful and vice versa. The researchers still find that $24.70 \%$ of community members in this study do not adopt individual hygiene because they do not perceive the usefulness of healthy behaviors. Healthy life is increasing needs and demand although in the reality the health degree of Indonesian people has not meet the expectation (Priyoto, 2014).

Individual hygiene does not only provide prevention toward certain disease in the family health but also wider positive impact in order to prevent the disease outbreak to other people. Therefore, parents' knowledge and attitude are very important in order to understand the benefits of individual hygiene toward Diarrhea prevention and to teach clean and healthy behaviors toward their children as early as possible (Brown et al., 2013).

\section{The influence of perceived barriers toward Diarrhea-preventing beha- viors}

The results of this study show that there has been direct influence from perceived barriers toward Diarrhea-preventing behaviors $(b=0.12 ; p=0.032)$. This implies that an individual who perceives many barrierss during his or her absorption of hygienic behaviors will have smaller possibility to adopt Diarrhea-preventing behaviors than the one who does not perceives any barrierss while performing his or her diseasepreventing behaviors.

Perceived barriers are a negative aspect that potentially inhibits the performance of health efforts (side effects, uncertainty) or the barriers that have been perceived to influence the recommendation of new behaviors introduction (anxious, incompatible, unhappy and nervous) (Taylor, 2007; Romano, 2014).

The results of this study are in accordance to a study by Smith et al., which state that an individual who does not perform individual hygiene has greater possibility to consider that adopting these behaviors might be costly. Bariers in performing disease-preventing behaviors include: cost, culture and difficulty in providing facilities (sufficient facilities and clean water are not available) (Asamani, 2011; Freeman et al., 2014). The awareness toward barriers that might appear needs anticipation and needs to be calculated within the healthy behaviors of an individual both as prevention and as preliminary handling of the health problems that he or she has. In a healthy behavior, barriers that have occured might be imaginary or real.

Barriers in this study are expensive cost, unavailable sanitation facilties and norms/ cultures. Perceived barriers are a significant element in determining whether there has been any changes or not. In rela- 
Journal of Health Promotion and Behavior (2017), 2(1): 1-14

https://doi.org/10.26911/thejhpb.2017.02.01.01

tion to new behaviors that should be adopted, an individual should believe that the benefits of these new behaviors are greater than the consequences of continuing the old behaviors. Zetu et al. (2013) stated that therehasbeen relationship between perceived barriers and disease-preventing behaviors in which the problems of cost becomes a barrier in pursuing healthy behaviors. Last but not the least, the results of this study are also in accordance to the theory of HBM which explains that the perceived barriers might act as a barrier in performing the recommended behaviors (Romano, 2014).

The results of description on the perceived barriers show that $26.00 \%$ subjects feel the barries to turn their negative behaviors into the positive ones. For example, one of these subjects used to be taught by their parents that they should perform healthy behavior by defecating in the river but not they should adopt a new healthy behavior by defecating in the water closet. In order to change this behavior, he should believe that barriers and consequences of individual hygiene behaviors are smaller than continuing the old behaviors. In order to change this behavior as well, an understanding toward the differences between old and new behaviors should be disseminated along with the impacts that might occur due to the outbreak of a disease in their settlement.

\section{The influence of cues to action to- ward Diarrhea-preventing beha- viors}

The results of the study show that there has been direct influence from cues to action toward Diarrhea-preventing behaviors $(b=$ $0.17 ; \mathrm{p}=0.003)$. This implies that an individual who have cues to action from medical staff, medical cadres, relatives and neighbors regarding the importance of individual hygiene for his or her health will have greater possibility to adopt Diarrheapreventing behaviors than the one who does not have cues to action.

Cues to action is the action-triggering factors that might come from the individual alone (the appearance of the symptoms of certain diseases) or from the external aspects (others' suggestions, health campaign, getting affected by similar disease that colleagues or family members have). Cues to action is a factor that accelerates an individual to take action or take real action for the sake of his or her health (Clasen et al., 2007; Asamani, 2011; Bakhtari, 2012).

Cues to action involves ilness of a family member, media reports (Dreibelbis et al., 2013), mass media campaign, others' suggestions and medical staff's suggestion (Sigler et al., 2015). The presence of cues, education, symptoms or information media (cues to action) might influence an individual in terms of the danger of a disease; as a result, he or she will take action. Most of the stimuli from the external aspects of an individual comes as perceived objects. The perceived objects are categorized into two parts namely non-human objects and human objects. If the perceived objects are human then the perceived individual will influence the perceiving individual (Priyoto, 2014).

Within the theory of HBM, in order to decrease the sense of being threatened, there should be an offer of action alternative by medical staff (Rosenstock, 1982; Burke, 2013). Whether the individual approves the proposed alternative or not depends on the individual's view regarding benefits and barriers of the alternative implementation. The individual will consider whether the alternative might decrease the threat of getting affected by a disease along with its negative impact. On the contrary, the negative consequence of the proposed action alternative (problems of 
cost, shame, fear toward pain and alike) often causes the individual to avoid implementing the recommended alternative (Nelas et al., 2015).

In this study, the researchers still find community members who have not got cues to action (26.70\%); as a result, they have not understood the danger of Diarrhea and the importance of individual hygiene behaviors. The reason behind this finding is the low access that medical staff has to this region and the different level of individual socialization in each region, depending on their culture regarding illness and disease. It will be better if there is counselling that might be held every month in remote areas, especially in the riverbanks of Bengawan Solo, regarding individual hygiene behaviors in relation to defecating in water closet so that the community members' paradigm might change and the disease that might be sourced from unhealthy water and behaviors might be controlled.

\section{The influence of self-efficacy to- ward Diarrhea-preventing beha- viors}

The results of this study show that there has been direct influence from self-efficacy toward Diarrhea-preventing behaviors $(\mathrm{b}=$ 0.28 ; $\mathrm{p}<0.001$ ). This implies that an individual who has strong self-efficacy (selfcapacity) in performing individual hygiene behaviors will have greater possibility to adopt Diarrhea-preventing behaviors than the one who has weak self-efficacy.

Strong self-efficacy makes an individual to put aside barriers and to strive performing his or her role optimally. Family support is one of the factors that influence an individual's behaviors in taking right decisions. The presence of family support might encourage behavioral capacity and willingness (Freeman et al., 2014). High self-efficacy might cause an individual to endure longer in more difficult problems, to throw away ineffective problem solving activities, to be quicker in selecting strategies, to review any mistakes in their work, to prepare themselves toward more challengeing objectives to spend lesser time in being anxious toward the consequences of failure (WSP, 2008). Zetu et al. (2013) suggested that self-efficacy hasbeen related to a belief that an individual has the capacity to performing expected positive actions.

Behaviors are determined by motive and confidence regardless whether the motive or the confidence is in accordance to the reality or to the others' view or not regarding what is the best for the individual. This opinion/confidence might be in accordance to the reality, but might also be different to the reality as having been seen by other people. Although it might be different, according to Rosenstock (1982) it has been this subjective opinion that instead becomes the key to perform (or not to perform) a healthy action. This implies that an individual will perform medicating actions if he or she is truly threatened by the disease. If he or she is not confident with his or her capacity in performing the behaviors, then this individual might do nothing.

In this study, the researchers find 19.30\% subjects who are still not confident to their self-efficacy in performing preventing behaviors. The inconfidence on their self-efficacy to provide sufficient facility makes them not to do the recommended behaviors (Weaver et al., 2016). It will be better if government optimizes the aid on sufficient sanitation facilities toward community members who have problems of cost so that each member has sufficient sanitation in order to support the change of their behaviors. In addition, health education regarding the use of clean water closet should be improved in order to change the paradigm of villagers regarding 
Journal of Health Promotion and Behavior (2017), 2(1): 1-14

https://doi.org/10.26911/thejhpb.2017.02.01.01

the danger that they have if they keep continuing the old habits in order that the number of Diarrhea cases might be decreased. The confidence on self-efficacy determines how an individual behave. An individual will not try to do something unless if the individual thinks that he or she can do it.

There are six variables that significantly have direct influence toward Diarrhea-preventing behaviors, namely perceived severity/ seriousness $(b=0.26 ; p<0.001)$, perceived threats $(b=0.29 ; p<0.001)$, perceived benefits $(b=0.21 ; p<0.001)$, perceived barriers $(b=-0.12 ; p<0.032)$, cues to action $(b=0.17 ; p=0.003)$ and selfefficacy $(b=0.28 ; p<0.001)$. On the other hand, there are three variables that significantly have indirect influence toward Diarrhea-preventing behaviors namely perceived vulnerability $(b=0.55 ; p<0.001)$, perceived severity/ seriousness $(b=0.34 ; p$ $<$ o.001) and perceived benefits $(b=0.12 ; \mathrm{p}$ $=0.025$ ).

\section{REFERENCE}

Anup KC (2012). A Descriptive Study On Water Sanitation Hygiene and Diarrhoeal Morbidity Among Under Five Years Children at Community LED Total Sanitation Elicited Area In Nawalparasi. Department of Public Health, School of Health and Allied Sciences, Pokhara University, Kaski, Nepal 2012.

Asamani C (2011). Water, Sanitation and Hygiene (WASH) Behaviour Change Communication (BCC) strategy for The Urban Sub-Sector. USAID. http:// www.globalcommunities.org/publicati ons/2011-ghana-wash-bcc-strategy.pdf. Diakses November 2016.

Bakhtari AF, Zadeh NR, Sahebi L (2012). Effect of Education Based on Health Belief Model on Believe Promotion and
Screening Behaviours of Breast Cancer Among Women Reffered to Tabriz Health Centers. Medl J Tabriz Uni Medl Sci 33: 25-31.

Brown J, Cairncross, Ensink (2013). Water, Sanitation, Hygiene And Enteric Infections In Children. Arch Dis Child 98: 629-634.

Burke E (2013). The Health Belief Model. www.iccwa.org.au. Diakses Maret 2016.

Clasen T, Schmidt WP, Rabie T, Roberts I, Cairncross $S$ (2007). Interventions to Improve Water Quality for Preventing Diarrhoea: Systematic Review and Meta-Analysis. BMJ 334(782).

Dinkes Jateng (2016). Profil Kesehatan Provinsi Jawa Tengah tahun 2015. Dinas Kesehatan Provinsi Jawa Tengah. http://dinkesjatengprov.go.id/v2015/ dokumen/profil2015/Profil_2015_fix.p df. Diakses Desember 2016.

Dinkes Sragen (2016). Profil Kesehatan Kabupaten Sragen tahun 2014. Dinas Kesehatan Sragen. http://www.depkes.go.id/resources/download/profil/PROFIL_KAB_KOTA_2014/3314_Ja teng_Kab_Sragen_2014.pdf. Diakses Oktober 2016.

Dreibelbis R, Winch PJ, Leontsini E, Hulland K, Ram P, Unicomb L, Luby S (2013). The Integrated Behavioural Model for Water, Sanitation, and Hygiene. BMC Public Health, 13:1015. http://www. biomedcentral.com/14712458/13/1015.

Fauziah IN, Djuari L, Arief YS (2015). Pengembangan Model Perilaku Ibu dalam Pencegahan Gizi Buruk Balita. Jurnal Ners 10(2): 195-207.

Freeman M, Stocks M, Cumming O, Jeandron A, Higgins J, Wolf J (2014). Hygiene and Health: Systemic review of Handwashing Practices Worldwide and Update of Health Effect. Tropical 
Medicine \& International Health, 19 (8): 906-916. Doi: 10.1111/tmi.12339.

Geetha J \& Kumar S (2014). Open Defecation: Awareness \& Practices of Rural Districts of Tamil Nadu, India. International Journal Of Scientific Research 3(5): 537-539.

Gristwood J (2011). Applying The Health Belief Model to Physical Activity Engagement Among Older Adult. Illuminare: A Student Journal In Recreation, Parks and Leisure Studies 9(1): 59-71.

Hayden J (2010). Health belief theory. USA: Jones and Bartlett Publisher.

ISSDP (2015). Percepatan program STBM 2013-2015. Indonesian Studi Sanitation Sector Development Program. http://pppl. Depkes.go.id/_asset/_download/ROADMAP\%20STBM.pdf.

Diakses Maret 2017.

Jasper C, Le T, Bartram J (2012). Water and Sanitation In Schools: A Systematic Review of The Health and Educational Outcomes. Int $\mathrm{J}$ Environ Res Public Health 9: 2772-2787.

Kemenkes RI (2013). Profil Kesehatan Indonesia 2012. Kementerian Kesehatan RI. http://www.depkes.go.id/resources/ download/pusdatin/profil-kesehatan-indonesia/profil-kesehatan-indonesia-2012.pdf. Diakses Oktober 2016. (2015). Rencana Strategis

Kementrian Kesehatan Tahun 20152019. Keputusan Menteri Kesehatan RI No.HK.02.02/MENKES/52/2015. http: //www.depkes.go.id/resources/download/info-publik/Renstra-2015.pdf.Di akses Nevember 2016.

(2016). Menuju 100\% Akses

Sanitasi Indonesia 2019. Kementerian Kesehatan RI. http://www.depkes.go.id/ article/ print/ 16060100003/menuju-10o-akses-sanitasi-indonesia2019.html. Diakses November 2016.
(2016). Profil Kesehatan Indonesia 2015. Kementerian Kesehatan Republik Indonesia 2016. http://www. depkes.go.id/resources/download/pusdatin/profil-kesehatan-indonesia/profil-kesehatan-Indonesia-2015.pdf. Diakses November 2016.

Magar B, Kaphle H, Gupta N (2016). Open Defecation Free Status of Magdi District of Nepal after Three Years Declaration: A Cross-Sectional Study. International Journal of Health Sciences and Research 6(9): 351-355.

Nelas P, Duarte J, Chaves C, Coutinho E, Amaral O (2015). Health Belief About Cervical Cancer in University Students. Procedia-Social and Behavioral Sciences 165: 189-194.

O'Connell K (2014). What Influences Open Defecation and Latrine Ownership in Rural Households? WSP \& World Bank. http://www.wsp.org/sites/wsp.org/files/publications/WSP-What-Influences-Open-Defecation-Global-Sanitation-Review. pdf. Diakses November 2016.

Orji R, Vassileva J, Mandryk (2012). Toward and Effective Health Interventions Design: An Extension of The Health Belief Model. Online Journal of Public Health Informatics. www.hci.usask.ca. Diakses Desember 2016.

Priyoto (2014). Teori sikap \& perilaku dalam kesehatan. Yogyakarta: Nuha Medika.

Romano V, Scott I (2014). Using Health Belief Model to Reduce Obesity Amongst African American and Hispanic Populations. Procedia - Social and Behavioral Science 159(23): 710-711.

Sigler R, Mahmoudi L, Graham J (2015). Analysis Behavioral Change Techniques in Community-Led Total Sanitation Programs. Health Promot Int 30 (1):16-28. Doi:10.1093/heapro/dauo73. 
Journal of Health Promotion and Behavior (2017), 2(1): 1-14

https://doi.org/10.26911/thejhpb.2017.02.01.01

Smith PJ, Humistog SG, Marcuse SK, Zhao Z, Dorell CG, Howes C (2011). Parental delay or refusal of vaccine doses childhood vaccination coverage at 24 months of age, and the health belief model. Public Health Rep 2: 135-146.

Sukut S, Arif Y, Qur'aniati N (2015). Faktor Kejadian Diare Pada Balita dengan Pendekatan Teori Nola J. Pender Di IGD RSUD Ruteng. Jurnal Pediomaternal 3(2): 230-249.

Taosu SA dan Azizah R (2013). Hubungan Sanitasi Dasar Rumah dan Perilaku Ibu Dengan Kejadian Diare Pada Balita di Desa Bena, Nusa Tenggara Timur. Jurnal Kesehatan Lingkungan 7(1): 1-6.

Taylor D, Bury M, Campling N, Carter S, Garfied S, Newbould J, Rennie T (2007). A Review of the use of The Health Belief Model (HBM), The Theory of Reasoned Action (TRA), The Theory of Planned Behaviour (TPB) and The Trans-Theoritical Model (TTM) to Study and Predict Health Related Behaviour Change. www.warwick.ac. uk. Diakses Desember 2015.

UNICEF Indonesia (2012). Air Bersih, Sanitasi dan Kebersihan. Ringkasan Kajian United for children. https://www.unicef.org/indonesia/id/A8_-

_B_Ringkasan_Kajian_Air_Bersih.pdf

. Diakses November 2016.

Vega N (2013). Knowledge, Attitudes and Traditions Regarding Water Consumption and Sanitary Practices of the Ngabe-Bugle Indigenous Women in the Chiriqui Panama. Graduate Theses and Dissertations University of South
Florida. http://scholarcommons.usf.edu/etd/4785.

Weaver ER, Agius PA, Veale H, Dorning K, Hlang TT, Aung PP (2016). Water, Sanitation Hygiene Facilities \& Hygiene Practices Associated with Diarrhea and Vomiting in Monastic Schools, Myanmar. Am. J. Trop. Med. Hyg 95 (2): 278-287.

WHO and UNICEF (2014). Progress on Drinking Water and Sanitation: 2014. https://www.unicef.org/gambia/Progr ess_on_drinking_water_and_sanitatio n_2014_update.pdf. Diakses Januari 2017.

Williams H, Gaines J, Patrick M, Berendes D, Fitter D, Handzel T (2015). Perceptions of Health Communication, Water Treatment and Sanitation in Artibonite Department, Haiti, March-April 2012. PLoS ONE, 10(11): e0142778. Doi: 10.1371/journal.pone.0142778.

WSP (2008). Developing a Sanitation Behavior Change Framework: SaniFOAM. Water and Sanitation. http:// www.wsp.org/sites/wsp.org/files/publicatio ns/SaniFOAM_Report409_3.pdf. Diakses Oktober 2016.

Zetu L, Zetu I, Dogaru C, Duta C, Dumitrescu (2013). Gender Variations in The Psychological Factors as Defined by The Extended Health Belief Model of Oral Hygiene Behaviors. ProcediaSocial and Behavioral Sciences 127: 358-362. 